\title{
Note on "Small Feedback-based Decisions and Their Limited Correspondence to Description-based Decisions"
}

\author{
Pavlo Blavatsky
}

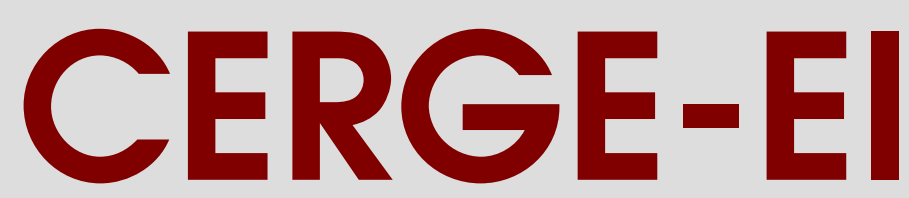

Charles University Center for Economic Research and Graduate Education Academy of Sciences of the Czech Republic Economics Institute 


\title{
Note on "Small Feedback-based Decisions and Their Limited Correspondence to Description-based Decisions"
}

\author{
Pavlo Blavatskyy* , CERGE-EI
}

October 2003

\begin{abstract}
:
Barron and Erev (2003) report experimental results revealing differences in risk attitude in small feedback-based problems as opposed to conventional description-based problems. This note shows that theoretical predictions drawing on a simple decision rule, known as the heuristic of relative probability comparisons (HRPC), fit the experimental data in Barron and Erev (2003) surprisingly well: even in the choice situation where the HRPC predicts an exact indifference the actual distribution of subject responses was $49 \%$ to $51 \%$.
\end{abstract}

\begin{abstract}
Abstrakt:
Barron and Erev (2003) uvádejí experimentální výsledky odhalující odlišné postoje $\mathrm{k}$ riziku $\mathrm{v}$ malých zpetnovazebních problémech oproti konvencním na popisu založeným problémum. Tato práce ukazuje, že teoretické predikce založené na jednoduchém rozhodovacím pravidle, známé jako HRPC, prekvapive dobre odpovídají experimentálním datum Barrona and Ereva (2003): dokonce i ve vyberových situacích, kde HRPC predikuje presnou indiferenci, bylo aktuální rozložení odpovedí subjektu 49\% až $51 \%$.
\end{abstract}

Keywords: Heuristic of relative probability comparisons, feedback-based decisions

JEL Classification codes: C91, D11

Author's contacts: Pavlo Blavatskyy, c/o CERGE-EI, P.O.B. 882, Politickych veznu, 7

11121 Prague-1, Czech Republic

e-mail: pavlo.blavatsky@ cerge-ei.cz

Phone: +420224005248

${ }^{*}$ I am grateful to Greg Barron, Ido Erev, Andreas Ortmann and Avner Shaked for helpful comments. 


\section{Note on "Small Feedback-based Decisions and Their Limited Correspondence to Description-based Decisions"}

Barron and Erev (2003) report experimental results revealing differences in risk attitude in small feedback-based problems as opposed to conventional description-based problems. The authors propose a learning model that explains the obtained experimental results. This note demonstrates that a simple decision rule is sufficient for explaining their main results (aggregate modal choice) without recourse to learning models, which can be too complex for this purpose. Specifically, I show that theoretical predictions drawing on the heuristic of relative probability comparisons (HRPC) (Blyth, 1972; BarHillel and Margalit, 1988; Blavatskyy, 2003) fit the experimental data in Barron and Erev (2003) surprisingly well: even in the choice situation where the HRPC predicts an exact indifference the actual distribution of subject responses was $49 \%$ to $51 \%$.

For the remainder of this note the following definitions are used. A lottery is a probability distribution over discrete and finite outcomes. Lotteries are distributed independently. The realized outcome of a lottery is called the payoff of a lottery. The infinite sequence of payoffs of several lotteries is called the joint distribution of lotteries.

It seems now widely accepted that people often use heuristics—or rules of thumb, i.e. decision rules that simplify decision problems (Gigerenzer et al., 1999). Each heuristic describes certain preferences. By definition, the HRPC describes a preference for a lottery that is most probable to bring a higher payoff than all other available lotteries. The exact algorithm of the HRPC is the following. First, in a joint distribution of all feasible lotteries, an individual estimates the probability of each lottery to yield an 
undominated payoff. For each lottery this probability is its relative probability to outperform all other available lotteries. Second, an individual compares all relative probabilities. This specific action gives the heuristic its name-the heuristic of relative probability comparisons. Third, an individual chooses the lottery with the highest relative probability.

For example, consider the choice set $\{A, B\}$. Lottery $A$ yields 2 with probability $2 / 3$ and 5 with probability $1 / 3$. Lottery B gives 3 with certainty. Two states of the world are possible in the joint distribution of lotteries. In the first state, the payoff of $A$ is 2 and the payoff of $B$ is 3. The payoff of $A$ is dominated in this state of the world. The probability of this state is $2 / 3$. In the second state, the payoff of $A$ is 5 and the payoff of $B$ is 3. The payoff of $B$ is dominated in this state of the world. The probability of this state is $1 / 3$. The probability that $B$ brings a higher payoff than $A$ is $2 / 3$, which is greater than $1 / 3$ - the relative probability of $A$ winning over $B$. Thus, in accordance with the HRPC $B$ is preferred to $A$.

Clearly, the HRPC is ordinal in outcomes. This property makes it an optimal decision procedure when only ordinal information about lottery outcomes is available. In general, the applicability of the HRPC depends on whether the probability of particular events is central to a decision and whether outcomes can be taken as ordinal. One class of decision problems where the HRPC appears to be efficiently applicable is the choice between lotteries with equal, or similar, expected value. Blavatskyy (2003) provided experimental evidence of its viability in such a context. 
Blyth (1972) described the HRPC as a criterion of maximum likelihood to be the greatest. Bar-Hillel and Margalit (1988) described the HRPC as a preference for a probabilistically prevailing lottery. Blavatskyy (2003a) built an axiomatization of the HRPC and demonstrated that the HRPC is a special case of regret theory (Loomes and Sugden, 1982) when outcomes are perceived as ordinal and the assumption of regret aversion is relaxed.

Barron and Erev (2003) experimentally studied individual decision making in small feedback-based problems where the choice situation is repeated many times, alternatives have similar (small) expected values and the distribution of lotteries is unknown to the subjects. Below I will review eight feedback-based problems of choice between discrete outcome lotteries ${ }^{1}$ employed in Barron and Erev (2003) and demonstrate that the revealed modal choice (averaged over 400 trials and 48 subjects) is always consistent with the theoretical prediction from the HRPC. Barron and Erev (2003) clustered these problems in four experiments. My discussion follows their grouping.

Decision making in the domain of gains. Following Kahneman and Tversky (1979), Barron and Erev (2003) studied a choice between 3 with certainty and 4 with probability 0.8 (zero otherwise). The HRPC predicts the choice of the second lottery which is more probable to yield a higher payoff. With probability 0.8 it brings 4 as

\footnotetext{
${ }^{1}$ In replicating the main finding of Thaler et al. (1997) Barron and Erev (2003) studied three feedbackbased problems where lottery payoff was drawn from a continuous distribution. This note does not consider these problems because the HRPC is defined as a decision rule over discrete outcome lotteries. It is mathematically straightforward to extend the HRPC to continuous probabilistic distributions. However, then the heuristic requires an action of double integration and loses its appeal as a simple decision rule. Alternatively, it is possible to discretize the continuous probabilistic distributions, which quite possibly is the way subjects deal cognitively with such a situation. Since, however, such a discretization is somewhat arbitrary, I will not offer such an analysis here.
} 
opposed to 3 and only with probability 0.2 does it bring zero as opposed to 3 . Consistent with this prediction, in the experiment $63 \%$ of subjects chose the second lottery.

Now, consider a choice between 3 with probability 0.25 and 4 with probability 0.2 (zero otherwise). With probability 0.2 the second lottery brings 4 whereas the first lottery brings either 3 or 0 . Thus, the probability that the second lottery outperforms the first lottery is 0.2 . With probability $0.25 \cdot(1-0.2)=0.2$ the first lottery brings 3 whereas the second lottery brings 0 . Thus, the probability that the first lottery outperforms the second lottery is also 0.2. The HRPC predicts that an individual should be indifferent between these two lotteries. Consistent with this prediction, in the experiment $49 \%$ of subjects chose the first lottery and $51 \%$ of the subjects chose the second lottery.

Decision making in the domain of losses. Barron and Erev (2003) studied a choice between -3 with certainty and -4 with probability 0.8 (zero otherwise). The HRPC predicts the choice of the first lottery which is more probable to yield a higher payoff. With probability 0.8 it brings -3 as opposed to -4 and only with probability 0.2 does it bring -3 as opposed to 0 . Consistent with this prediction, in the experiment $60 \%$ of subjects chose the second lottery.

Decision making when lotteries have equal expected value. The above problems involved lotteries with similar but not equal expected values. Barron and Erev (2003) studied a choice between 9 with certainty and 10 with probability 0.9 (zero otherwise). The HRPC predicts the choice of the second lottery, which brings 10 as opposed to 9 with probability 0.9 and only with probability 0.1 does it bring 0 as opposed to 9 . Consistent with this prediction, in the experiment $56 \%$ of subjects chose the second 
lottery. Consider a choice between -9 with certainty and -10 with probability 0.9 (zero otherwise). The HRPC predicts the choice of the first lottery, which brings -9 as opposed to -10 with probability 0.9 and only with probability 0.1 does it bring -9 as opposed to 0 . Consistent with this prediction, in the experiment $63 \%$ of subjects chose the first lottery.

Decision making when lotteries involve small probabilities. Barron and Erev (2003) studied a choice between 3 with certainty and 32 with probability 0.1 (zero otherwise). The HRPC predicts the choice of the first lottery, which brings 3 as opposed to 0 with probability 0.9 and only with probability 0.1 does it bring 3 as opposed to 32 . Consistent with this prediction, in the experiment $72 \%$ of subjects chose the first lottery. Consider a choice between 3 with probability 0.25 and 32 with probability 0.025 (zero otherwise). The HRPC predicts the choice of the first lottery, which brings 3 as opposed to 0 with probability $0.25 \cdot(1-0.025) \approx 0.244$ and only with probability 0.025 does it bring either 3 or 0 as opposed to 32 . Consistent with this prediction, in the experiment $70 \%$ of subjects chose the first lottery. Consider a choice between -3 with certainty and 32 with probability 0.1 (zero otherwise). The HRPC predicts the choice of the second lottery, which brings 0 as opposed to -3 with probability 0.9 and only with probability 0.1 does it bring -32 as opposed to 0 . Consistent with this prediction, in the experiment $60 \%$ of subjects chose the second lottery.

In sum, the aggregate modal choice is always predicted correctly by the HRPC. However, in some choice problems the aggregate modal choice is rather low (about 60\%). One possible explanation might be that in the Barron and Erev (2003) study the actual probability distribution of lotteries was unknown to the subjects. Thus, the subjects 
have to engage in a number of random trials (exploration trials) to infer the frequency of lottery outcomes. The experimental evidence of Barron and Erev (2003) suggests, in any case, that the HRPC is a plausible decision rule in a binary choice between discrete outcome lotteries with similar expected values when probability information is presented via direct experience. 


\section{References}

Barron, G. \& Erev, I. (2003). Small Feedback-Based Decisions and Their Limited Correspondence to Description-Based Decisions. Journal of Behavioral Decision Making, 16, 215-233.

Bar-Hillel, M. \& Margalit, A. (1988). How vicious are cycles of intransitive choice? Theory and Decision, 24, 119-145.

Blavatskyy, P. (2003). Content-dependent preferences in choice under risk. Part one: empirical evidence. CERGE-EI discussion paper.

Blavatskyy, P. (2003a). Content-dependent preferences in choice under risk. Part two: axiomatization. CERGE-EI discussion paper.

Blyth, C. (1972). Some Probability Paradoxes in Choice from Among Random Alternatives. Journal of the American Statistical Association, 67, 366-382.

Gigerenzer, G., Todd, P., \& the ABC Research Group (1999). Simple Heuristics That Make Us Smart. Oxford University Press.

Kahneman, D., \& Tversky, A. (1979). Prospect theory: an analysis of decision under risk. Econometrica, 47, 263-291.

Loomes, G. \& Sugden, R. (1982). Regret theory: an alternative theory of rational choice under uncertainty. Economic Journal, 92, 805-824.

Thaler, R., Tversky, A., Kahneman, D., \& Schwartz, A. (1997). The effect of myopia and loss aversion on risk taking: an experimental test. Quarterly Journal of Economics, 112, 647-661. 
CERGE-EI

P.O.BOX 882 Politických vezòù 7

11121 Prague 1

Czech Republic http://www.cerge-ei.cz 